\title{
Neochamberlainia, a new name for Chamberlainia Artabe, Zamuner \& D. W. Stev. (Zamiaceae) non Chamberlainia Grout (Brachytheciaceae)
}

\author{
Analia Artabe ${ }^{1}$, Alba B. Zamuner ${ }^{1}$, and Dennis W. Stevenson ${ }^{2}$ \\ ${ }^{1}$ CONICET, Department of Paleobotany, Facultad de Ciencias Naturales y Museo de La Plata, \\ UNLP, Paseo del Bosque S/N, 1900, La Plata, Argentina \\ ${ }^{2}$ Author for correspondence: The New York Botanical Garden, Bronx, NY 10458-5120, USA; \\ e-mail: dws@nybg.org
}

Artabe et al. (2005) described a new fossil cycad genus, Chamberlainia, from the Allen Formation (Late Cretaceous) of Baja de Santa Rosa, Río Negro Province, Argentina. Unfortunately, this name is preoccupied by a moss genus in the Brachytheciaceae, described by Grout (1928). Thus, Chamberlainia Artabe, Zamuner \& D. W. Stev. is a later homonym (Art. 53.1, ICBN Vienna) and a new name is required.

Neochamberlainia Artabe, Zamuner \& D. W. Stev., nom. nov. Chamberlainia Artabe, Zamuner \& D. W. Stev., Alcheringa 29: 88, Figs. 2 \& 3. 2005, nom. illeg., non Grout, Moss Fl. N. Amer. 3: 27. 1928.

Type: Neochamberlainia pteridospermoidea (Artabe, Zamuner \& D. W. Stev.) Artabe,
Zamuner \& D. W. Stev., comb. nov. Chamberlainia pteridospermoidea Artabe, Zamuner \& D. W. Stev., Alcheringa 29: 89, Figs. 2 \& 3. 2005.

\section{Acknowledgments}

We thank Robert Mill for calling our attention to the earlier use of the genus name, and James L. Reveal for advice.

\section{Literature Cited}

Artabe, A. E., A. B. Zamuner, \& D. W. Stevenson. 2005. A new genus of Late Cretaceous cycad stem from Argentina, with reappraisal of known forms. Alcheringa 29: 87-100.

Grout, A. J. 1928. Chamberainia nov. gen. In: Moss Flora of North America, North of Mexico 3: 27-28. 